\title{
Pengaruh Produk Domestik Bruto, Tingkat Suku Bunga Tabungan Bank Konvensional dan Nisbah Bagi Hasil Terhadap Jumlah Tabungan Mudharabah
}

The effect of gross domestic product, conventional bank savings interest rates and profit sharing ratios on total mudharabah savings

\section{Ghina Fauziyyah Umami}

Program Studi D4 Keuangan Syariah, Politeknik Negeri Bandung

E-mail: ghina.fauziyyah.ksy15@polban.ac.id

\section{Fatmi Hadiani}

Jurusan Akuntansi, Politeknik Negeri Bandung

E-mail: fatmi.hadiani@polban.ac.id

\section{Radia Purbayati}

Jurusan Akuntansi, Politeknik Negeri Bandung

E-mail: radia.purbayati@polban.ac.id

\begin{abstract}
This study aims to utilize the potential funding sources through mudharabah savings by analyzing several factors that are thought to affect the amount of mudharabah savings. The research method used in this study is a quantitative approach by using multiple linear regression analysis as an analysis method and SPSS 25.0 as analysis tool. The results of the research are variables of Gross Domestic Product (PDB) and Savings Interest Rate of Conventional Banks (SBT) have significant effect on the amount of mudharabah savings. Partially, PDB has positive effect while SBT has negative effect. On the other side, variable of Profit Sharing Ratio (NBH) has no significant effect on the amount of mudharabah savings. All of three independent variables simultaneously affected the amount of mudharabah savings in BSM.
\end{abstract}

Keywords: mudharabah savings, gross domestic product, savings interest rate, profit sharing ratio

\section{Pendahuluan}

Setelah beberapa dekade didirikan, perkembangan bank syariah di Indonesia mengalami peningkatan yang cukup baik. Terbukti dari jumlah kantor cabang bank umum syariah (BUS) yang terus-menerus didirikan. Puncaknya adalah pada tahun 2014 yaitu sebanyak 2.163 kantor, dimana jumlah tersebut merupakan peningkatan dari tahun 2010 yang berjumlah sebesar 1.215 kantor.

Berkembangnya perbankan syariah di Indonesia seharusnya berdampak juga pada perekonomian Indonesia, tetapi jika dibandingkan dengan perbankan konvensional, peran perbankan syariah terhadap perekonomian Indonesia masih terbilang kecil dalam skala perbankan nasional.

Di Indonesia hanya terdapat satu bank syariah yang sudah menembus buku 3, sedangkan sisanya masih berada pada buku 1 dan buku 2. Dapat disimpulkan bahwa perkembangan aset perbankan di Indonesia didominasi oleh bank umum konvensional meskipun terdapat fluktuasi dari jumlah aset tersebut pada setiap tahunnya. Menurut besarnya aset, pada tahun 2017 bank 
umum konvensional mencapai 96\% dari total asset perbankan Indonesia. Artinya, bank syariah hanya turut berkontribusi sebesar $4 \%$ saja dari total asset. Hal itu sangat disayangkan jika menilik bahwa Indonesia merupakan negara yang mayoritas penduduknya adalah muslim.

Perkembangan asset bank syariah itu sendiri dipengaruhi oleh peran utama bank syariah sebagai lembaga penghimpunan dan penyaluran dana masyarakat. Aset bank syariah didapatkan dari penghimpunan dana masyarakat dimana terdapat beberapa jenis simpanan dalam menghimpun dana masyarakat diantaranya adalah simpanan dalam bentuk giro, tabungan, dan deposito. Jenis simpanan pada bank syariah yang memiliki porsi terbesar dalam keseluruhan dana pihak ketiga adalah tabungan mudharabah, sehingga perkembangan tabungan mudharabah dapat dijadikan sebagai salah satu tolak ukur perkembangan asset suatu bank Syariah serta dapat mencerminkan minat masyarakat terhadap jasa bank Syariah.

Tabel 1. Perkembangan Tabungan Mudharabah di Bank Umum Syariah

(Dalam Milyar Rupiah)

\begin{tabular}{|c|r|r|r|r|r|r|}
\hline \multirow{2}{*}{ Tahun } & \multicolumn{7}{|c|}{ Bank Umum Syariah Tahun 2010 } \\
\cline { 2 - 8 } & $\begin{array}{c}\text { PT Bank } \\
\text { Syariah } \\
\text { Muamalat } \\
\text { Indonesia }\end{array}$ & $\begin{array}{c}\text { PT Bank } \\
\text { Syariah } \\
\text { Mandiri }\end{array}$ & $\begin{array}{c}\text { PT Bank } \\
\text { Syariah } \\
\text { Mega } \\
\text { Indonesia }\end{array}$ & $\begin{array}{c}\text { PT Bank } \\
\text { Syariah } \\
\text { BRI }\end{array}$ & $\begin{array}{c}\text { PT Bank } \\
\text { Syariah } \\
\text { Bukopin }\end{array}$ & $\begin{array}{c}\text { Panin } \\
\text { Syariah }\end{array}$ \\
\hline 2010 & 500.21 & $2.492,10$ & 389,18 & 23,27 & 0,51 & 3,71 \\
\hline 2011 & $1.128,31$ & $4.116,61$ & 201,67 & 48,79 & 36,42 & 3,63 \\
\hline 2012 & $2.301,16$ & $4.014,89$ & 289,35 & 92,50 & 50,47 & 22,38 \\
\hline 2013 & $2.467,07$ & $2.278,10$ & $-519,11$ & 86,10 & 139,20 & 39,53 \\
\hline 2014 & $2.487,85$ & 645,53 & $-76,49$ & 92,43 & 1,60 & $-3,38$ \\
\hline 2015 & $-2.822,62$ & $1.248,51$ & $-65,65$ & 322,38 & 9,36 & $-15,44$ \\
\hline 2016 & $-797,90$ & $1.962,45$ & 139,20 & 286,92 & 107,17 & 42,06 \\
\hline 2017 & 499,87 & $3.208,90$ & 126,54 & 287,36 & $-38,95$ & 204,36 \\
\hline
\end{tabular}

Sumber: Laporan Keuangan Bank Umum Syariah 2009-2017 (Diolah)

Tabel 1. menjelaskan perkembangan tabungan mudharabah BSM merupakan salah satu perkembangan yang dapat terlihat jelas dan fluktuatif jika dibandingkan dengan lima BUS lainnya, sehingga dapat mewakili kondisi perbankan syariah di Indonesia. Fluktuasi tersebut dapat dipengaruhi beberapa faktor yang berasal dari lingkup internal maupun eksternal.

Beberapa faktor makroekonomi yang diduga dapat mempengaruhi tabungan mudharabah di Indonesia adalah pendapatan dan tingkat suku bunga tabungan pada bank konvensional. Menurut Sukirno (Dalam Novianto dan Hadiwidjoyo, 2013), dalam analisis makroekonomi digunakan istilah pendapatan nasional atau national income, dengan demikian dalam penggunaan istilah tersebut pendapatan nasional adalah mewakili arti produk domestik bruto. Produk Domestik Bruto (PDB) diduga dapat mempengaruhi tabungan sesuai dengan sebuah teori ekonomi klasik yang mengatakan bahwa tabungan merupakan hasil dari pendapatan yang dikurangi konsumsi. Sedangkan tingkat suku bunga tabungan pada bank konvensional menjadi salah satu penarik nasabah untuk menyimpan dananya di bank.

Faktor internal yang diduga dapat mempengaruhi jumlah tabungan mudharabah pada BSM adalah nisbah bagi hasil. Dalam menentukan hasil atas sebuah simpanan, bank syariah menggunakan sistem bagi hasil karena menerapkan prinsip syariah. Sehingga nisbah bagi hasil inilah yang digunakan menjadi insentif bagi nasabah yang menyimpan dana di bank syariah. 


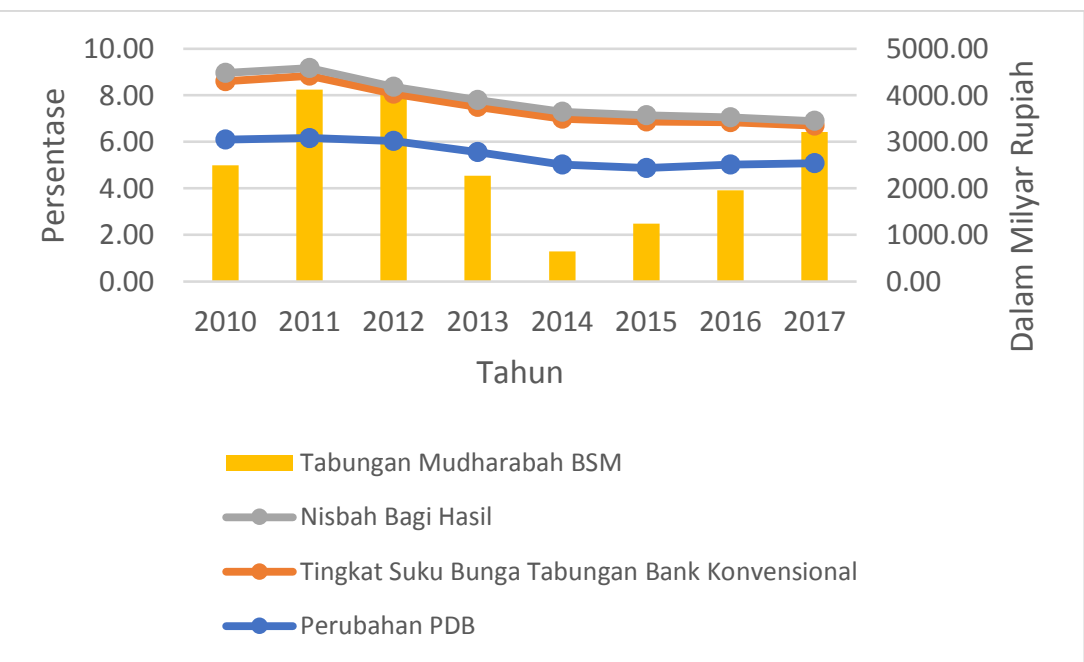

Gambar 1. Faktor yang Dapat Mempengaruhi Tabungan Mudharabah BSM Sumber: OJK dan BPS (Diolah)

Grafik pada Gambar 1 menggambarkan kondisi dari ketiga faktor yang diduga dapat mempengaruhi jumlah tabungan mudharabah pada BSM. PDB yang merupakan indikator makroekonomi yang menunjukkan pendapatan nasional negara dari sembilan faktor secara statistika, perubahannya mengalami fluktuasi dari tahun ke tahun. Penurunan perubahan PDB tersebut dapat terlihat jelas pada tahun 2014. Kedua faktor lain yaitu tingkat suku bunga tabungan bank konvensional dan nisbah bagi hasil juga mengalami penurunan dari tahun 2011.

Merujuk pada teori Keynes, seharusnya jumlah tabungan pada bank turut mengalami penurunan pada periode tersebut karena adanya penurunan perubahan PDB dan nisbah bagi hasil. Pada penelitiannya, Haron dan Norsofiza (Dalam Rudiansyah, 2014) menunjukkan bahwa terdapat hubungan yang positif antara PDB dan jumlah simpanan di bank syariah. Namun pendapat yang berbeda diungkapkan oleh penelitian Ali, Hassan, \& Kasim (2012) dimana membuktikan tidak ada pengaruh antara PDB dan jumlah simpanan di bank Syariah.

Fluktuasi tabungan mudharabah pada BSM mengalami penurunan pada tahun 2012 dan puncak penurunannya pada tahun 2014, kemudian beranjak naik pada tahun 2015 sampai dengan tahun 2017. Berdasarkan fluktuasi, penurunan yang terjadi pada tabungan mudharabah di BSM tidak memiliki kesesuaian dengan penurunan yang terjadi pada PDB dan nisbah bagi hasil tabungan mudharabah BSM.

Tingkat suku bunga tabungan bank konvensional yang merupakan pembanding bagi hasil pada bank syariah juga mengalami penurunan dari tahun 2011 sampai 2017. Tingkat suku bunga tabungan yang turun pada bank konvensional dapat membuat nasabah lebih memilih bank syariah dibandingkan bank konvensional. Perkembangan tabungan mudharabah menghadapi persaingan antara tingkat suku bunga tabungan bank konvensional dan nisbah bagi hasil yang akan diterima nasabah. Besarnya tabungan mudharabah juga dipengaruhi oleh besarnya pendapatan nasabah.

\section{Kajian Pustaka}

\subsection{Tabungan Mudharabah}

Tabungan mudharabah menggunakan akad mudharabah dimana tabungan jenis ini dapat juga dikatakan sebagai tabungan investasi. Pada akad mudharabah, terdapat nisbah bagi hasil antara mudharib dan shabibul mal. Baik keuntungan ataupun kerugian akan menjadi tanggungan kedua belah pihak berdasarkan nisbah bagi hasil yang telah ditentukan di awal kesepakatan saat terjadi akad. Tujuan dari tabungan mudharabah adalah agar dana yang dititipkan oleh nasabah kepada bank 
dapat dikelola agar mendapat manfaat dibandingkan jika dana tersebut hanya didiamkan sehingga menjadi idle money atau uang yang menganggur.

\subsection{Produk Domestik Bruto (PDB)}

Menurut Mc Eachern (2000:146) dalam Rudiansyah (2014), pengertian Produk Domestik Bruto (PDB) adalah jumlah nilai pasar dari barang dan jasa akhir yang diproduksi oleh sumber daya yang berada dalam suatu negara selama jangka waktu tertentu, biasanya satu tahun. Produk Domestik Bruto juga dapat digunakan untuk mempelajari perekonomian dari waktu ke waktu.

\subsection{Suku Bunga}

Teori klasik menyatakan bahwa bunga adalah bagian dari penggunaan dana yang tersedia untuk dipinjamkan (loanable fund). Sedangkan menurut Case dan Fair (2001:635), suku bunga adalah pembayaran bunga tahunan dari suatu pinjaman, dalam bentuk persentase dari pinjaman yang diperoleh dari jumlah bunga yang diterima tiap tahun dibagi dengan jumlah pinjaman. Tingkat suku bunga tabungan merupakan persentase suku bunga yang akan didapatkan dalam melakukan simpanan berbentuk tabungan pada bank syariah.

\subsection{Bagi Hasil}

Bagi hasil merupakan konsep yang diterapkan pada akad kerja sama dalam perekonomian Islam. Menurut terminologi asing (Bahasa Inggris), bagi hasil dikenal sebagai profit sharing yang diartikan sebagai laba atau keuntungan dalam ilmu ekonomi. Sedangkan menurut Agustianto (2005:56) dalam Suratman (2013), bagi hasil adalah keuntungan atau hasil yang diperoleh dari pengelolaan dana baik investasi maupun transaksi jual beli yang diberikan nasabah. Bagi hasil harus ditentukan dan ditetapkan pada awal terjadinya akad dan besarnya harus disepakati oleh kedua pihak yang bersangkutan. Kedua pihak akan mendapatkan keuntungan sesuai dengan porsi atau nisbah bagi hasil yang telah disetujui sebelumnya dalam pembagian hasil keuntungan tersebut. Nisbah inilah yang akan menentukan jumlah yang akan didapatkan bank dan nasabah.

\subsection{Keterkaitan Antar Variabel}

Produk domestik bruto (PDB) digunakan sebagai variabel yang mewakili pendapatan nasional pada penelitian ini. Nurjanah dan Sumiyarti (2009) dalam penelitiannya menyatakan bahwa dalam kaitan antara pendapatan, konsumsi dan tabungan diketahui bahwa tidak semua pendapatan yang diterima akan digunakan untuk konsumsi, melainkan sebagian akan disimpan. Maka dapat dikatakan bahwa tabungan merupakan bagian dari pendapatan yang tidak dikonsumsi dalam periode tertentu. Sehingga kenaikan dalam pendapatan diduga akan dapat mempengaruhi peningkatan tabungan serta konsumsi. Oleh karena itu, antara pendapatan nasional dan simpanan memiliki hubungan yang positif.

Menurut Boediono (1994:76), tingkat suku bunga merupakan salah satu indikator dalam menentukan apakah seseorang akan melakukan investasi atau menabung. Artinya, masyarakat menggunakan suku bunga dalam memutuskan akan menyimpan dananya di bank atau tidak. Apabila tingkat suku bunga dalam hal ini adalah suku bunga tabungan dapat menjadi faktor penentu keputusan untuk menabung di bank konvensional, maka tingkat suku bunga dapat juga menjadi alasan masyarakat untuk lebih memilih menyimpan dana di bank konvensional dibandingkan bank syariah. Oleh karena itu, tingkat suku bunga tabungan bank konvensional diduga dapat mempengaruhi jumlah tabungan mudharabah di bank syariahh.

Pada sistem bagi hasil di bank syariah, keuntungan yang akan dibagikan merupakan keuntungan bersih atau net profit yang didapatkan dari selisih pengurangan total cost terhadap total revenue. Bagi hasil digunakan sebagai pembanding suku bunga pada bank konvensional. Artinya, jika masyarakat mengharapkan imbalan atas simpanannya pada bank 
konvensional dengan melihat suku bunga, maka ketika masyarakat menyimpan dana pada bank syariah yang akan mereka dapatkan adalah berupa nisbah bagi hasil. Sehingga bagi hasil diduga akan dapat mempengaruhi keinginan masyarakat untuk menyimpan dana di bank syariah.

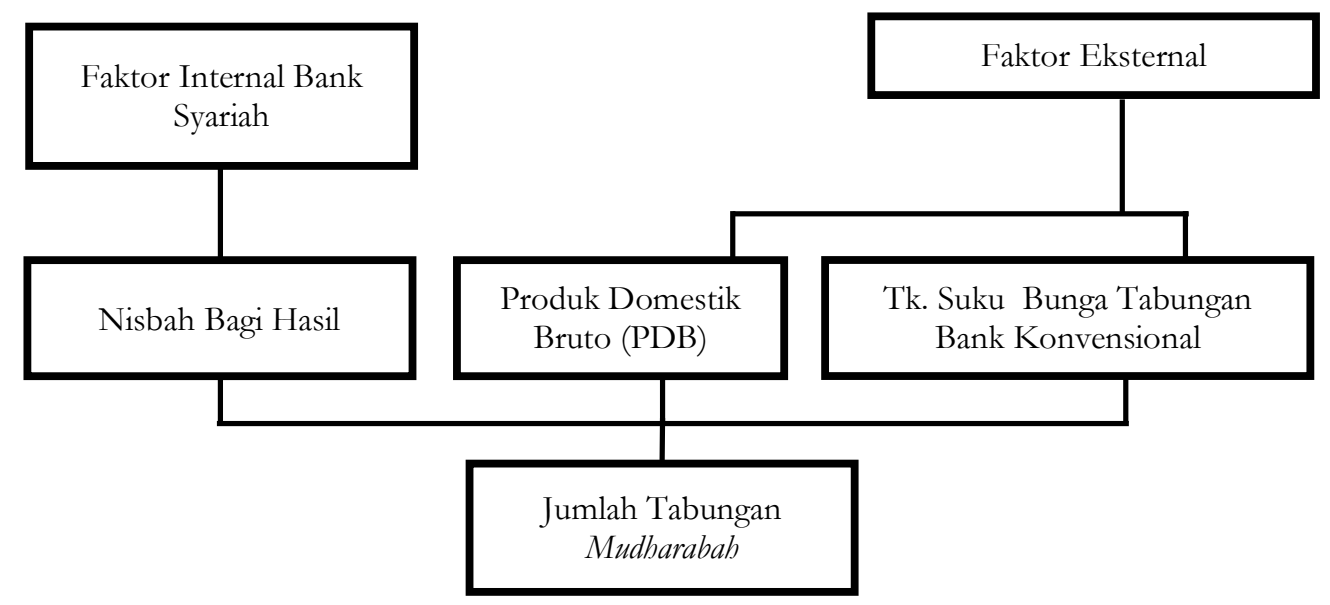

Gambar 2. Kerangka Pemikiran

Sumber: Diolah Penulis adalah:

Berdasarkan kajian teoritis dan penelitian terdahulu, maka hipotesis dalam penelitian ini

$\mathrm{H}_{1}$ : PDB berpengaruh secara parsial terhadap Jumlah Tabungan Mudharabah di Bank Syariah Mandiri periode 2011-2018.

$\mathrm{H}_{2}$ : Tingkat Suku Bunga Tabungan Bank Konvensional berpengaruh secara parsial terhadap Jumlah Tabungan Mudharabah di Bank Syariah Mandiri periode 2011-2018.

$\mathrm{H}_{3}$ : Nisbah Bagi Hasil berpengaruh secara parsial terhadap Jumlah Tabungan Mudharabah di Bank Syariah Mandiri periode 2011-2018.

$\mathrm{H}_{4}$ : PDB, Tingkat Suku Bunga Tabungan Bank Konvensional dan Nisbah Bagi Hasil

berpengaruh secara simultan terhadap Jumlah Tabungan Mudharabah di Bank Syariah Mandiri periode 2011-2018.

\section{Metode Penelitian}

Metode yang digunakan pada penelitian ini adalah metode deskriptif dengan pendekatan kuantitatif yang ditujukan untuk memperoleh gambaran secara sistematis mengenai pengaruh yang dimiliki variabel independen terhadap variabel dependen. Populasi dalam penelitian ini adalah PT Bank Syariah Mandiri sejak pertama didirikan hingga sekarang. Penelitian ini menggunakan teknik purposive sampling dalam menentukan sampel dimana sampel yang akan digunakan adalah PT Bank Syariah Mandiri periode 2011 sampai 2018 berupa data triwulanan sebanyak 32 sampel dari masing-masing variabel.

Penelitian ini menggunakan analisis regresi linier berganda untuk menganalisis besarnya hubungan dan pengaruh variabel independen yang jumlahnya lebih dari dua, yang mengharuskan data untuk diuji asumsi klasik dimana menguji ada atau tidaknya gejala-gejala normalitas, autokorelasi, multikoinearitas dan heteroskedastisitas dengan bantuan software SPSS (Statistical Product and Service Solution) versi 25.0. Sehingga dihasilkan model regresi linier bergandaa dengan spesifikasi model sebagai berikut:

$$
T M=a+b_{1} P D B+b_{2} S B T+b_{3} N B H+e
$$


Dimana:

TM : Tabungan mudharabah

$P D B \quad$ : Produk Domestik Bruto

SBT : Tingkat Suku Bunga Tabungan Bank Konvensional

NBH : Nisbah Bagi Hasil

a : Konstanta

$b_{1}, b_{2}, b_{3}$ : Koefisien regresi variabel independen

e : Error

\section{Hasil dan Pembahasan}

\subsection{Hasil Penelitian} berikut:

Setelah dilakukan pengujian menggunakan SPSS 25.0 didapat perhitungan pada tabel

Tabel 2. Koefisien Regresi Berganda

\begin{tabular}{|l|l|r|r|r|r|r|}
\hline \multicolumn{2}{|l|}{} & \multicolumn{2}{|l|}{ Unstandardized Coefficients } & Standardized Coefficients & & \\
\cline { 3 - 7 } \multicolumn{2}{|l|}{ Model } & B & Std. Error & Beta & \multicolumn{1}{c|}{ S } & Sig. \\
\hline \multirow{1}{*}{1} & (Constant) & -.697 & 1.764 & & -.395 & .696 \\
& PDB (X1) & 1.312 & .267 & .548 & 4.909 & .000 \\
& SBT (X2) & -.166 & .027 & -.464 & -6.249 & .000 \\
& NBH (X3) & -.00003932 & .002 & -.002 & -.021 & .984 \\
\hline
\end{tabular}

a. Dependent Variable: TM (Y)

Sumber: Hasil Olah SPSS 25.0 (Diolah Penulis) berganda:

Berdasarkan perhitungan pada Tabel 2, maka diperoleh persamaan regresi linear

$$
Y=-0,697+1.312 \mathrm{PDB}-0,166 \mathrm{SBT}-0,00003932 \mathrm{NBH}
$$

Persamaan 1 dapat menjelaskan bahwa konstanta sebesar - 0,697 adalah jumlah tabungan mudharabah ketika variabel independen yaitu PDB, SBT dan NBH adalah nol, maka TM akan berkurang sebesar 0,697. Peningkatan PDB sebesar 1 satuan akan meningkatkan TM sebanyak 1,312. Sedangkan peningkatan SBT sebesar 1 satuan akan mengurangi TM sebanyak 0,166. Sementara peningkatan NBH sebesar 1 satuan akan mengurangi TM sebanyak 0,00003932.

Dalam melakukan analisis menggunakan alat analisis regresi linier, data terlebih dahulu harus melalui uji asumsi klasik yang terdiri dari uji normalitas, uji autokorelasi, uji multikolinearitas, dan uji heteroskedastisitas. Berdasarkan hasil uji normalitas Kolmogorov-Smimov, nilai signifikansi sebesar $0,075>0,05$, dan dapat disimpulkan bahwa nilai residual berdistribusi normal. Nilai DurbinWatson adalah sebesar 1,108, dimana berdasarkan ketentuan pengambilan keputusannya, maka dapat disimpulkan bahwa pada model regresi iini tidak terdapat autokotelasi karena nilai dw berada diantara -2 dan +2 atau $-2<1,108<+2$. Tolerance pada masing-masing variabel bebas berada di atas 0,100 , sedangkan nilai VIF dari masing-masing variabel bebas berada di bawah $<10,00$. Maka dapat disimpulkan bahwa pada model regresi ini tidak terdapat gejala multiikolinearitas yang artinya tidak terdapat korelasi antar variabel bebas. Metode yang digunakan untuk menguji heteroskedastisitas pada penelitian ini adalah Uji Glejser dengan hasil perhitungan nilai signifikansi dari ketiga variabel independent lebih besar dari 0,05. Artinya, tidak lterjadi hetroskedastisitas pada model regresi ini. 
Hasil pengujian untuk koefisien korelasi didapat angka $\mathrm{R}$ sebesar 0,982 yang menunjukkan bahwa korelasi atau hubungan antara ketiga variabel dependen dengan variabel independennya adalah kuat karena angka $\mathrm{R}$ tersebut diatas 0,5 . Sementara nilai $\mathrm{R}$ Square atau koefisien determinasi yaitu 0,964 . Hal ini berarti $96,4 \%$ variasi dari jumlah tabungan mudharabah pada BSM dapat dijellaskan oleh variasi dari ketiga variabel bebas tersebut. Sedangkan sisanya yaitu 3,6\% dapat dijelaskan oleh sebab-sebab lainnya. Tingginya nilai $\mathrm{F}$ statistik menunjukkan bahwa model ini sudah benar dan variabel yang digunakan sudah sesuai dengan tujuan penelitian yang akan dicapai.

Hasil dari uji t memperlihatkan bahwa nilai signifikansi variabel PDB adalah 0,000 dimana nilai tersebut lebih kecil dari 0,05, maka PDB berpengaruh signifikan terhadap jumlah tabungan mudharabah di BSM dengan arah koefisien positif. Variabel SBT berpengaruh signifikan terhadap variabel jumlah Tabungan Mudharabah di BSM yang ditunjukkan oleh nilai signifikansi variabel SBT yaitu 0,000 dimana nilai tersebut lebih kecil dari 0,05 . Sedangkan variabel $\mathrm{NBH}$ tidak berpengaruh signifikan terhadap variabel jumlah Tabungan Mudharabah BSM karena nilai siignifikansi variabel $\mathrm{NBH}$ adalah 0,984 dimana nilai tersebut lebih besar dari 0,05.

Berdasarkan perhitungan didapat F-hitung yaitu 247,354. Selanjutnya F-tabel diperoleh dengan menghitung nilai V1 dan V2. Tingkat signifikansi yang digunakan pada penelitian ini adalah $\alpha=5 \%$ atau 0,05 . V1 didapatkan dari nilai $\mathrm{k}$ yaitu 3 , atau dapat dilihat pada tabel yaitu $\mathrm{df}$ regression. Sedangkan V2 didapatkan dari $\mathrm{n}-\mathrm{k}$ dimana $\mathrm{n}=32$ dan $\mathrm{k}=3$. Sehingga diperoleh V2 yaitu 29, atau dapat dilihat pada tabel yaitu df residual. Maka diperoleh nilai F-tabel sebesar 2,92. Nilai F-hitung lebih besar dari F-tabel maka $\mathrm{H}_{0}$ ditolak dan $\mathrm{H}_{1}$ diterima. Dapat disimpulkan bahwa variabel Produk Domestik Bruto $\left(\mathrm{X}_{1}\right)$, Tingkat Suku Bunga Tabungan Bank Konvensional $\left(\mathrm{X}_{2}\right)$, Nisbah bagi hasil $\left(\mathrm{X}_{3}\right)$, berpengaruh terhadap jumlah Tabungan Mudharabab PT Bank Syariah Mandiri secara bersamasama (simultan).

\subsection{Pembahasan Hasil Penelitian}

\section{Pengaruh Variabel Produk Domestik Bruto terhadap Jumlah Tabungan Mudharabah di BSM}

Hasil estimasi dengan pendekatan model regresi menunjukkan bahwa dari ketiga variabel bebas, hanya lvariabel Produk Domestik Bruto (PDB) yang secara parsial berpengaruh signifikan terhadap jumlah Tabungan Mudharabah. Arah koefisien PDB bertanda positif yang berarti ketika pendapatan masyarakat yang ditunjukkan oleh PDB meningkat, maka jumlah tabungan mudharabah juga meningkat. Hasil signifikan positif tersebut dapat dilihat dari perkembangan PDB Indonesia pada tahun 2011 sampai dengan tahun 2018 yang cenderung mengalami peningkatan setiap tahunnya, yang mengindikasikan bahwa pendapatan nasional masyarakat terus mengalami peningkatan.

Dapat dikatakan bahwa besarnya pendapatan masyarakat akan sangat berpengaruh terhadap besarnya tabungan, karena pendapatan yang diterima masyarakat tidak hanya digunakan untuk kebutuhan konsumsi tetapi juga digunakan untuk menabung di bank. Artinya, masyarakat sangat mempedulikan kebutuhan di masa yang akan datang sehingga masyarakat akan memperbesar jumlah tabungannya jika pendapatannya mengalami peningkatan.

Terdapat sebuah teori yang juga sesuai dengan hasil penelitian ini, yaitu teori Keynes yang menyatakan bahwa besarnya tabungan yang mampu dihimpun ditentukan juga oleh besarnya pendapatan masyarakat. Dalam hal ini tabungan mudharabah masyarakat akan mengalami peningkatan karena adanya peningkatan pendapatan masyarakat yang direpresentasikan oleh PDB.

Hasil penelitian ini sesuai dengan penelitian yang telah dilakukan Rudiansyah (2014) yang juga menunjukkan bahwa PDB secara parsial berpengaruh signifikan terhadap simpanan mudharabah pada bank isyariah. Secara teori simpanan mudharabah masyarakat pada bank syariah 
akan meningkat karena adanya kelebihan konsumsi yang ditabung untuk kebutuhan di masa yang akan datang. Sehingga dalam tahunan pun jumlah simpanan mudharabah di bank syariah sejalan dengan perkembangan PDB di Indonesia.

Beberapa penelitian lainnya yang memiliki hasil sesuai dengan hasil penelitian ini adalah penelitian yang dilakukan Wibowo (2004), serta Nurjanah dan Sumiyarti (2010). Namun penelitian ini tidak mendukung hasil penelitian yang dilakukan oleh Novianto dan Hadiwidjojo (2013), serta penelitian Ali, Hassan dan Kasim (2012) yang menunjukkan bahwa PDB tidak berpengaruh secara signifikan terhadap simpanan mudharabah. Perbedaan hasil tersebut dapat disebabkan oleh perbedaan periode dan objek penelitian yang digunakan. Beberapa penelitian dilakukan sekaligus pada beberapa Bank Umum Syariah di Indonesia, namun penelitian ini merupakan studi kasus pada PT Bank Syariah Mandiri sehingga hasil yang diperoleh hanya berlaku pada PT Bank Syariah Mandiri.

\section{Pengaruh Variabel Tingkat Suku Bunga Tabungan Bank Konvensional terhadap Jumlah Tabungan Mudharabah di BSM}

Berdasarkan pengujian yang telah dilakukan, variabel Tingkat Suku Bunga Tabungan Bank Konvensional secara parsial berpengaruh signifikan terhadap tabungan mudharabah di BSM. Arah koefisien yang negatif menunjukkan bahwa ketika SBT mengalami penurunan, akan terjadi peningkatan tabungan mudharabah.

Besarnya tingkat suku bunga tabungan di bank konvensional yang berbanding terbalik dengan jumlah tabungan mudharabah di BSM dapat menunjukkan bahwa keputusan masyarakat untuk menabung di bank syariah berkaitan erat dengan menurunnya tingkat suku bunga tabungan di bank konvensional. Ketika tingkat suku bunga tabungan di bank konvensional mengalami penurunan, masyarakat akan cenderung menyimpan dananya di bank syariah, begitu juga sebaliknya. Sehingga dapat dikatakan bahwa motif masyarakat dalam menyimpan dana adalah untuk mencari imbal hasil yang besar atas dana yang disimpannya.

Hasill penelitian ini sesuai dengan pendapat yang diungkapkan oleh Boediono (1994:76) bahwa tingkat suku bunga merupakan salah satu indikator apakah seseorang akan melakukan investasi atau menabung.

Namun hasil penelitian ini tidak mendukung penelitian yang telah dilakukan oleh Nurjanah dan Sumiyarti (2010) serta Wibowo (2004), dimana suku bunga tidak berpengaruh signifikan terhadap simpanan mudharabah masyarakat di bank syariah.

\section{Pengaruh Variabel Nisbah Bagi Hasil terhadap Jumlah Tabungan Mudharabah di BSM}

Pengujian yang telah dilakukan terhadap variabel ketiga atau Nisbah Bagi Hasil menunjukkan bahwa secara parsial tidak berpengaruh signifikan terhadap tabungan mudharabah di BSM. Artinya, besaran NBH yang ditetapkan bank tidak memiliki pengaruh terhadap jumlah tabungan mudharabah yang didapatkan oleh BSM.

Tidak adanya pengaruh antara nisbah bagi hasil yang ditetapkan bank dengan jumlah tabungan mudharabah yang diperoleh dapat mengindikasikan bahwa keinginan masyarakat untuk menabung di BSM bukan karena imbalan bagi hasil yang dijanjikan dan ditetapkan oleh pihak bank, tetapi oleh faktor lainnya. Sehingga secara implisit dapat dikatakan bahwa besar kecilnya nisbah bagi hasil yang ditawarkan bank bukan menjadi daya tarik utama bagi masyarakat untuk menyimpan dana di bank syariah. Studi ini menggunakan data sekunder yang sangat umum dimana hanya melibatkan data mengenai variabel Tabungan Mudharabah dan Nisbah Bagi Hasil tabungan mudharabah di BSM sehingga tidak dapat menggambarkan persepsi dan pengetahuan masyarakat mengenai bank syariah itu sendiri. 


\section{Ghina Fauziyyah Umami, Fatmi Hadiani, Radia Purbayati}

Menurut Wibowo (2004), variabel tingkat bagi hasil yang tidak signifikan berpengaruh terhadap simpanan mudharabah menunjukkan bahwa kehendak masyarakat untuk menabung di bank syariah tidak dipengaruhi oleh motif untuk mendapatkan return berupa bagi hasil, tetapi oleh faktor lain yang tidak dapat ditemukan disini.

Hasil penelitian ini mendukung penelitian yang dilakukan oleh Nurjanah dan Sumiyarti (2010), yang menunjukkan bahwa dugaan variabel Nisbah Bagi Hasil menjadi salah satu faktor penentu simpanan di perbankan syariah menjadi tidak terbuktii.

Hasil penelitian ini juga sesusai dengan hasil penelitian Novianto dan Hadiwidjojo (2013) yang menyimpulkan bahwa pada beberapa masyarakat muslim, keputusan masyarakat untuk menyimpan dana di bank syariah tidak dipengaruhi oleh motif mencari keuntungan semata, namun dilandasi oleh semangat untuk saling tolong menolong/tabarru' dalam menggerakkan sektor riil dan adanya keyakinan yang kuat di kalangan masyarakat muslim akan unsur riba yang terdapat pada bunga bank konvensional yang dilarang agama Islam sebagaimana terdapat dalam Al-Qur'an.

\section{Penutup}

Variabel Produk Domestik Bruto (PDB) secara parsial berpengaruh signifikan terhadap jumlah Tabungan Mudharabah pada PT Bank Syariah Mandiri periode 2011-2018 dengan arah koefisien positif, yang sesuai dengan teori Keynes dimana peningkatan pendapatan masyarakat akan meningkatkan jumlah tabungan mudharabah.

Variabel Tingkat Suku Bunga Tabungan Bank Konvensional (SBT) secara parsial berpengaruh signifikan terhadap jumlah tabungan mudharabah PT Bank Syariah Mandiri periode 2011-2018 dengan arah koefisien negatif, yang menunjukkan bahwa keputusan masyarakat untuk menabung di BSM berkaitan erat dengan menurunnya tingkat suku bunga tabungan bank konvensional.

Nisbah Bagi Hasil (NBH) secara parsial tidak berpengaruh signifikan terhadap jumlah tabungan mudharabah PT Bank Syariah Mandiri periode 2011-2018. Hal tersebut mengindikasikan bahwa kecenderungan masyarakat untuk menyimpan dana di bank syariah bukan karena besarnya imbalan yang dijanjikan oleh bank, tetapi oleh faktor-faktor lain yang mungkin sangat terkaitt dengan pengetahuan dan persepsi masyarakat tentang bank syariah itu sendiri.

Produk Domestik Bruto (PDB), Tingkat Suku Bunga Tabungan Bank Konvensional (SBT), dan Nisbah Bagi Hasil (NBH) secara simultan berpengaruh terhadap jumlah tabungan mudharabah PT Bank Syariah Mandiri periode 2011-2018.

Variabel PDB, SBT dan NBH secara simultan berpengaruh terhadap TM karena berdasarkan nilai $R$ Square ketiga variabel tersebut dapat menjelaskan $96,4 \%$ dari jumlah tabungan mudharabah di BSM periode 2011-2018. Sementara 3,6\% sisanya dijelaskan oleh faktor-faktor lain. Artinya, variabel-variabel yang digunakan pada penelitian ini memiliki pengaruh yang kuat terhadap tabungan mudharabah di BSM sehingga dapat berpengaruh secara simultan.

Terdapat variabel-variabel non ekonomi yang turut mempengaruhi tabungan mudharabah, sehingga bank syariah diharapkan mampu meningkatkan pelayanannya dan harus lebih aktif mensosialisasikan ikepada masyarakat khususnya yang berada di pelosok daerah. Selanjutnya, meskipun variabel Nisbah Bagi Hasil tidak memiliki pengaruh pada penelitian ini, sebaiknya bank syariah menerapkan sistem transparansi atas perhitungan nisbah bagi hasil yang akan diterima masyarakat.

Saran untuk penelitian selanjutnya atas keterbatasan pada penelitian ini, yaitu dapat menambahkan variabel-variabel lain yang relevan dan potensial serta menggunakan alat analisis dan metode penelitian yang berbeda untuk mendapatkan hasil temuan yang dapat dibandingkan dengan penemuan-penemuan sebelumnya. 


\section{Daftar Pustaka}

Basu, Sudipta. (1997). The Conservatism Principle and The Asymetric Timelines of Earnings. New York: Journal of Accounting and Economics, Vol. 24, pp. 3 - 37.

Al-Qur'an dan Terjemahannya. Departemen Agama RI

Ali, S., Hassan, A. A., \& Kasim, K. (2012). Macroeconomics Variables and Its Impact to Mudharabah Investment Deposits in Malaysia, 51, 10866-10869.

Algifari. (2000). Analisis Regresi, Teori, Kasus dan Solusi. Yogyakarta: BPFE UGM.

Badan Pusat Statistik. (2018). Statistik PDB sampai Desember 2018. Jakarta, DKI: Penulis. Diakses dari https://www.bps.go.id

Bank Syariah Mandiri. (2019). Laporan Keuangan sepanjang periode yang dibutuhkan. Jakarta, DKI: Penulis. Diakses dari https://www.syariahmandiri.co.id/

Bank Syariah Mandiri. (2019). Informasi Perusahaan. Jakarta, DKI: Penulis. Diakses dari https://www.syariahmandiri.co.id/

Boediono. (1994). Ekonomi Moneter Seri Sinopsis Pengantar Ilmu Ekonomi Moneter. Yogyakarta: LPBFE.

Case, K. E., \& Fair, R. C. (2001). Prinsip-Prinsip Ekonomi Makro. Jakarta: Prenhalindo.

Case, K. E., \& Fair, R. C. (2007). Prinsip-Prinsip Ekonomi. Jakarta: Ekonisia.

Fatwa Dewan Syariah Nasional MUI Nomor 02/DSN-MUI/IV/2000 Tabungan. (2000). Retrieved from https://dsnmui.or.id/

Ghozali, I. (2011). Aplikasi Analisis Multivariate Dengan Program SPSS. Semarang: Badan Penerbit Universitas Diponegoro.

Kasmir. (2012). Bank dan Lembaga Kenangan Lainnya. Jakarta: PT Raja Grafindo Persada.

Kent, R. P. (1972). Money and Banking (6th Edition). Canada: Holt,Rinehart \& Winston of Canada Ltd. Diakses dari https://books.google.co.id

Mankiw, N. G. (2007). Makroekonomi (Edisi Keenam). Jakarta: Erlangga.

Martono. (2012). Manajemen Keuangan (Edisi Pertama). Yogyakarta: Ekonisia.

Masyhuri, \& Zainuddin, M. (2008). Metodologi Penelitian Sosial dan Ekonomi. Bandung: Alfabeta.

Nikensari, S. I. (2012). Perbankan Syariah: Prinsip, Sejarab \& Aplikasinya. Semarang: Pustaka Rizki Putra.

Novianto, A., \& Hadiwidjojo, D. (2013). Analisis Faktor-Faktor yang Mempengaruhi Penghimpunan Deposito Mudharabah Perbankan Syariah di Indonesia. Jurnal Aplikasi Manajemen, 11(4), 595-604.

Nurjanah, N., \& Sumiyarti, S. (2009). Pengaruh Nisbah Bagi Hasil , Produk Domestik Terhadap Simpanan Mudharabah Di Perbankan. Media Ekonomi, 18(1), 85-98.

Otoritas Jasa Keuangan. (2018). Laporan Keuangan Publikasi sepanjang periode yang dibutuhkan. Jakarta, DKI: Penulis. Diakses dari https://ojk.go.id/id/

Otoritas Jasa Keuangan. (2018). Statistik Perbankan Indonesia Desember 2018. Jakarta, DKI: Penulis. Diakses dari https://ojk.go.id/id/

Otoritas Jasa Keuangan. (2018). Statistik Perbankan Syariah Desember 2018. Jakarta, DKI: Penulis. Diakses dari https://ojk.go.id/

Prasetiantiono. (2000). Keluar Dari Krisis: Analisis Ekonomi Indonesia. Jakarta: Gramedia Pustaka Utama.

Republik Indonesia. Undang-Undang No.10 Tahun 1998 tentang Perbankan (1998). Indonesia. 
Republik Indonesia. Undang-Undang RI No. 21 Tahun 2008 tentang Perbankan Syariah (2008). Indonesia.

Rudiansyah, A. (2014). Pengaruh Inflasi, BI Rate, PDB DAN Nilai Tukar Rupiah Terhadap Simpanan Mudharabah Pada Bank Syariah di Indonesia. Jurnal Ilmu Manajemen, 2(2), 306-317.

Santoso, S. (2010). Statistik Parametrik, Konsep dan Aplikasi dengan SPSS. Jakarta: PT Elex Media Komputindo.

Sudarsono, H. (2012). Bank dan Lembaga Kenangan Syariah (Edisi Keempat). Yogyakarta: Ekonisia.

Sugiyono. (2011). Metode Penelitian Kuantitatif, Kualitatif dan R\&D. Bandung: Alfabeta.

Sunariyah. (2004). Pengantar Pengetahuan Pasar Modal (Edisi Keli). Bandung: CV Alfabeta.

Suratman. (2013). Pengaruh Jumlah Bagi Hasil Deposito Mudharabah, Tingkat Imbalan SBIS, Suku Bunga Simpanan Berjangka 1 Bulan, dan Inflasi terhadap Jumlah Deposito Mudharabah.

Tim Penyusun Standar Akuntansi Keuangan. (2002). Standar Akuntansi Keuangan. Jakarta.

White, H. (1968). Money and Banking. Diakses dari https://books.google.co.id/

Wibowo, M. G. (2004). Analisis Faktor-faktor yang Mempengaruhi Jumlah simpanan Nasabah Di Bank Syariah (Studi Kasus Bank Muamalat Indonesia), V(2), 130-147.

Wiroso. (2005). Penghimpun Dana dan Distribusi Hasil Usaha Bank Syariah. Jakarta: PT. Grasindo.

Wiroso. (2009). Penghimpunan Dana dan Distribusi Hasil Usaha Bank Syariah. Jakarta: PT Raja Grafindo Persada 